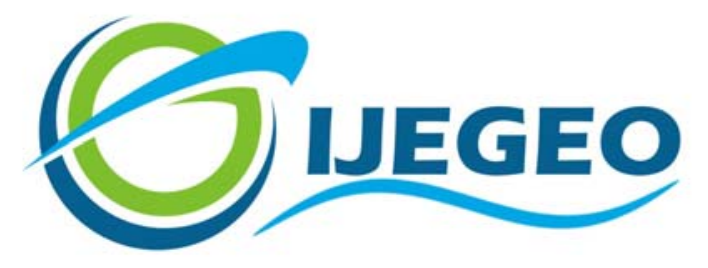

International Journal of Environment and Geoinformatics (IJEGEO) is an international, multidisciplinary, peer reviewed, open access journal.

\title{
Mapping South Tunisian Landscapes Using Remote Sensing and GIS Applications
}

\section{Faiza Khebour Allouche, Eric Delaître, Dalel Ouerchfeni Bousaida and Hanen Chaari}

\author{
Editors \\ Prof. Dr. Cem Gazioğlu, Prof. Dr. Dursun Zafer Şeker, Prof. Dr. Ayşegül Tanık, \\ Prof. Dr. Şinasi Kaya, Assist. Prof. Dr. Volkan Demir
}

\section{Scientific Committee (2018)}

Assist. Prof. Dr. Abdullah Aksu, Prof. Dr. Bedri Alpar, Prof. Dr. Gülşen Altuğ, Prof. Dr. Lale Balas, Prof. Dr. Can Balas, Prof. Dr. Levent Bat, Prof. Dr. Bülent Bayram, Prof. Dr. Nuray Çağlar, Prof. Dr. Jadunandan Dash, Prof. Dr. A. Evren Erginal, Assoc. Prof. Dr. Ali Ertürk, Dr. Dieter Fritsch, Dr. Amin Gharehbaghi, Assoc. Prof. Dr. Tolga Görüm, Prof. Dr. Melike Gürel, Dr. Hakan Kaya , Prof. Dr. Fatmagül Kılıç, Assoc. Prof. Dr. Maged Marghany, Prof. Dr. Nebiye Musaoğlu, Prof. Dr. Masafumi Nakagawa, Prof. Dr. Haluk Özener, Prof. Dr. Erol Sarı, Prof. Dr. Elif Sertel, Prof. Dr. Nüket Sivri, Assoc. Prof. Dr. Füsun Balık Şanlı, Prof. Dr. Uğur Şanlı, Assoc. Prof. Dr. Hasan Özdemir, Prof. Dr. Taşkın Kavzoğlu Assoc. Prof. Dr. Oral Yağcı, Prof. Dr. Seyfettin Taş, Assoc. Prof. Dr. Ömer Suat Taşkın, Assoc. Prof. Dr. İ. Noyan Yılmaz, Assist. Prof. Dr. Baki Yokeş, Assit. Prof. Dr. Sibel Zeki 


\title{
Mapping South Tunisian Landscapes Using Remote Sensing and GIS Applications
}

\author{
Faiza Khebour Allouche ${ }^{1,2^{*}}$, Eric Delaître ${ }^{3}$, Dalel Ouerchfeni Bousaida ${ }^{4}$, Hanen \\ Chaari $^{1}$ \\ ${ }^{1}$ BP47-4072 Sousse. University of Sousse, Sousse, Tunisia/ High Institute of Agronomic Sciences-Chott Meriem, \\ Departement of Horticultural Sciences and Landscape', \\ ${ }^{2} 43$ avenue Charles Nicolle. 1082 Tunis Mahrajène. Tunisie. Université de Carthage/ INAT/ Lr GREE TEAM \\ (LR17AGR01) \\ ${ }^{3} 911$ Avenue Agropolis, 34394 Montpellier, France /UMR-S ESPACE-DEV, IRD Montpellier, France. \\ ${ }^{4}$ Route du Jorf Km 22, Mednine, Tunisia/ Institute of Agronomic Research-Mednine, Tunisia. \\ Received: 13 Nov 2017 \\ $\begin{array}{llll}\text { Accepted } & 02 & \text { Feb } & 2018\end{array}$
}

\begin{abstract}
Oases of South Tunisia, plays an important role in environmental, social and economic aspects of this region. This research was conducted in ten regions located on the south which are affected by changes in conditions and composition of land cover change. For each study area, LANDSAT imagery, thematic maps and training data were acquired. These images were georeferenced and radiometrically corrected and landscapes product were generated using Decision Tree Classification. The landscapes typology were then evaluated using the extract oases. This study aimed to assess the potential of NDVI (Normalized Difference Vegetation Index) to determine oasis cover using medium spatial resolution remote sensing imagery in the south of Tunisia. It explores the possibility of identifying and mapping oasis landscape types by using remote sensing, Geographic Information Systems and statistical analysis. The superposition of environment types map obtained with oasis extracted from NDVI map has shown six oasis landscapes in southern Tunisia: Gafsa-ElGuettar, El Hamma de Gabes, Douz-Kebili, Rjim Maatoug, Tozeur-Nafta and Tamerza Chebika oases. This research paper allowed to define a methodology for the construction of landscape types, in a computerized way, based on remote sensing and GIS and its result can be a draft work to make an Atlas of the landscapes of our site of study or, it can be used as a basic document to monitor the spatial extension of agricultural perimeters in order to ensure the sustainable development of these particular agro-systems.
\end{abstract}

Keywords: Environment, GIS, NDVI, typology, landscape, oasis.

\section{Introduction}

In the south of Tunisia, available water resources are scarce and scattered. In most locations where water can be accessed, this resource is harnessed by oases planted to date palm (Phoenix dactylifera L.) and other crops. So far, little is known about different type of oases and there spatial location. Remote sensing, GIS and statistics techniques were used to locate oases, to characterize the sites according to their sol, relief and vegetation characteristics and to develop a typology of oases in southern Tunisia. From example, Ludeling and Buerkert (2008) have defined six types of Omani oases using this tools.
The objective is to characterize the oasis landscapes and to obtain a map of different oasis landscapes types. However, it represents a certain amount of data, formatted in a digital database, which must be processed in order to obtain representations which can be exploited subsequently. The approach adopted is to develop the principle according to which on the one hand landscapes are mapped on the scale of South Tunisia and on the other hand, the irrigated perimeters are extracted to finally be positioned oases in the southern Tunisian landscapes. 


\section{Materials and Methods Study Area}

The study was restricted to ten regions (Gabes, Ghannouch, Kebili, Douz, Gafsa, Mareth, Midès, El Guettar, Nefta and Tozeur) of the South of Tunisia, because LANDSAT images data for other regions were not available. Drought is a permanent feature of all these regions. However, the annual average rainfall varies from one area to another. Thus, the eastern coastal area receives about $200 \mathrm{~mm}$, while areas of continental western oasis receive only $90 \mathrm{~mm}$. Rainfall is erratic from one year to the other, they usually occur in the fall winter and spring and often take a stormy character (figure1).
The oasis in Tunisia occupy approximately 25,000 ha in four arid regions Northern border Saharan Fault Gafsa, Jerid, Nefzaoua and oasis edge Sea of Gabes. Between lebel Tebaga, Matmata Mountains and Chott El Jerid, the Nefzaoua is a vast miopliocène training 3,000 $\mathrm{km}^{2}$ that contains 8,400 acres of oasis (Santodirocco, 1986 and, Lasram, 1990). The south of tunisia covers 9.8 millions hectars, representing surroundings $60 \%$ of the tunesien total superficy and are located according to Le Houérou (1959) in his bioclimatic map in the saharan floor to cool winter for the Jerid and Nefzaoua oasis, and in the less arid and higher floor for the coastal, mountain oasis and there of Gafsa.

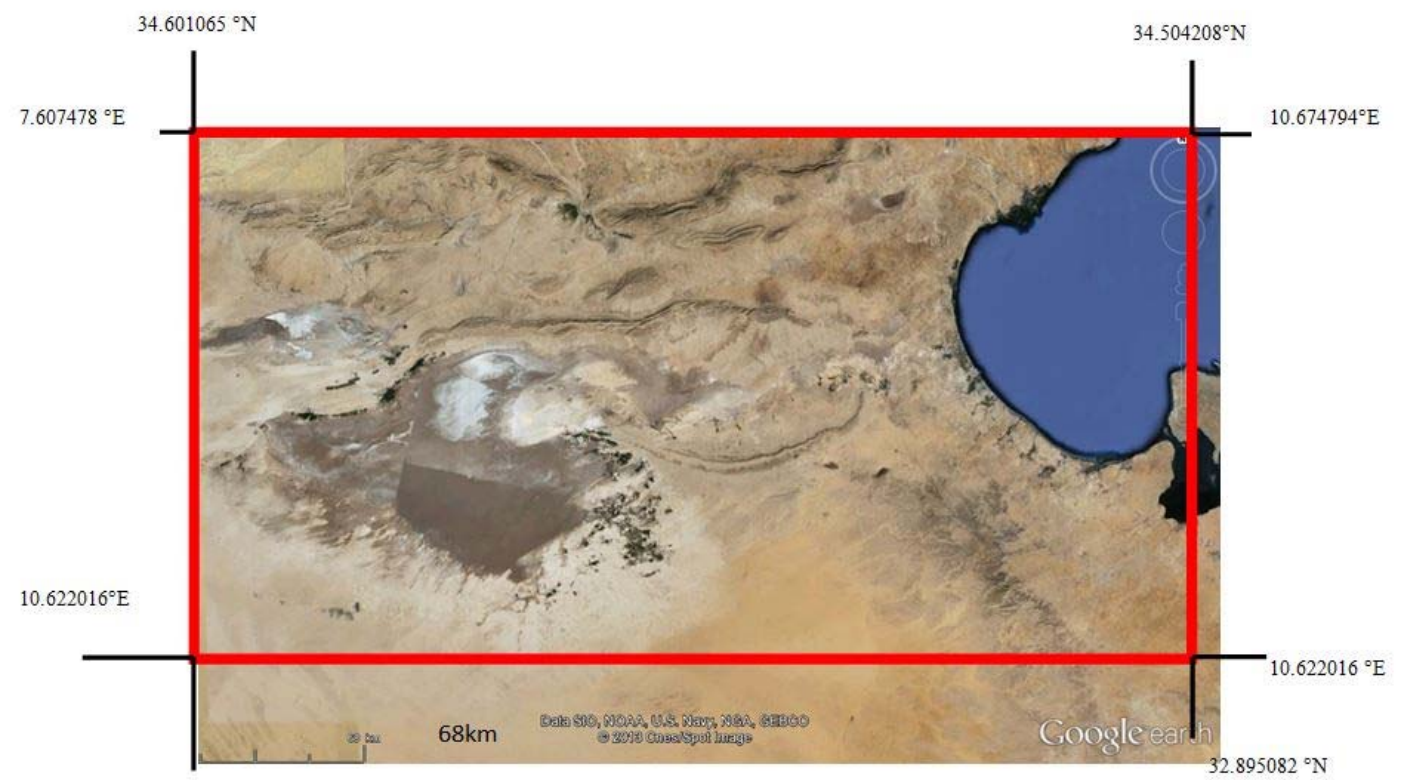

Fig 1. Location of the study area on the Southern Tunisia

\section{Processing LANDSAT TM imagery}

For this study, we acquired four LANDSAT 5 $\mathrm{TM}$ acquired during late summer or early fall (August-october), wich comprise a drier period at late growing season when many grasses and fobs are in senescence, but most shurbs and trees are still photosynthetically active (figure2). One image was acquired in the summer (August 7th 2011 ; TM, path 191, row 37 ), two images in septembre (September 15th
2011 ; TM, path 192 , rows 36 and 37) and one image on october 10th 2011 (TM, path 191 , row 36). The images were from the USGS Earth Ressources Observation Systems data center GLOVIS (Global Vizualisation Viewer) website and were delivered registered to a Universal Transverse Mercator (UTM) projection using a WGS84, Zone 32. The image processing system ENVI 4.5 was used in processing and classifying the acquired images. Preprocessing, such as geometric and 
radiometric correction were necessary before the analysis and were performed in order to reduce the radiometric distortion in the case of multi-date images of dry season on 2011. The LANDSAT 5 TM has seven spectral bands for land remote sensing with a spatial resolution of $30 \mathrm{~m}$ (bands 1-5 and 7) and $120 \mathrm{~m}$ for band 6 . All of the data sets were selected from relatively cloud-free

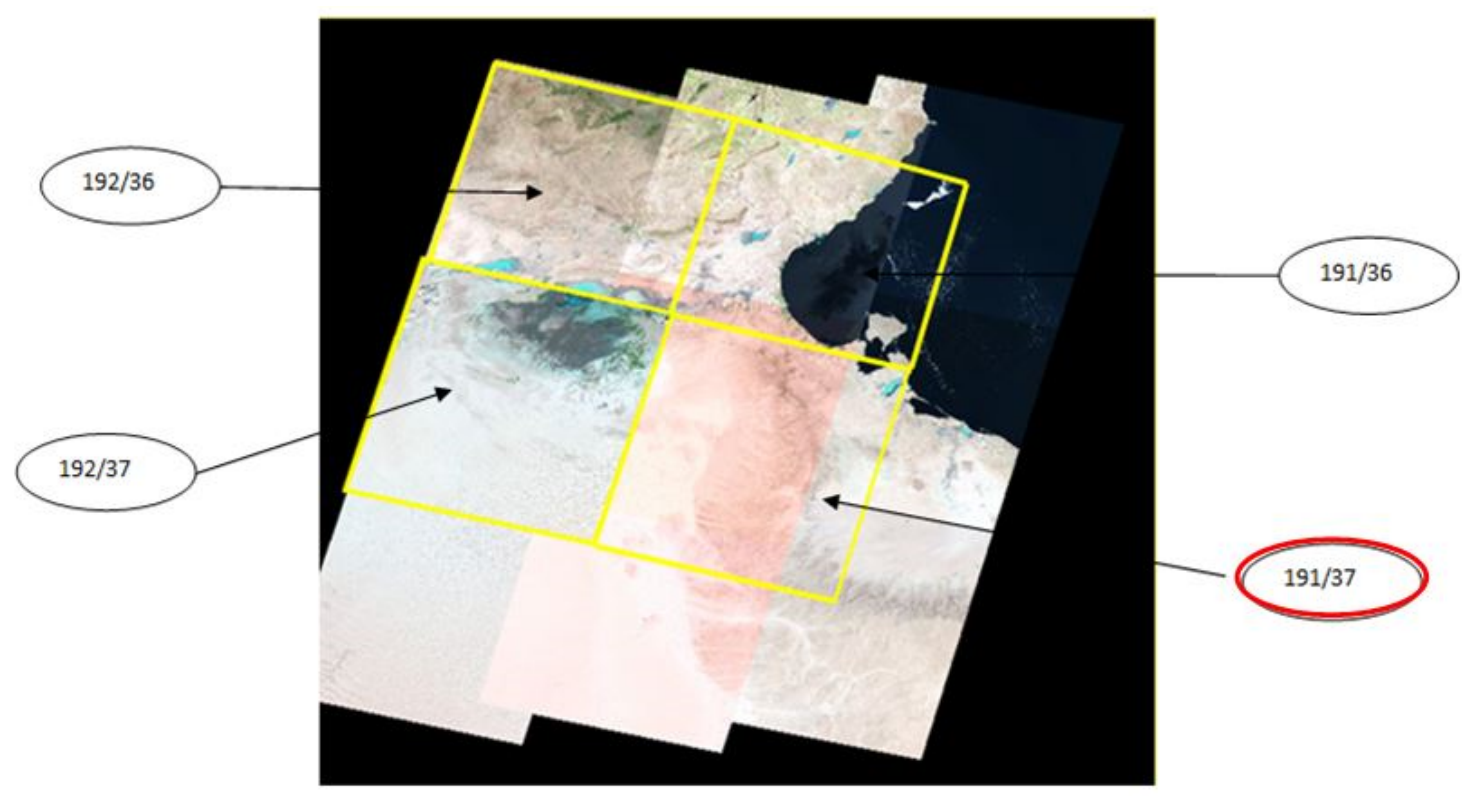

Fig 2. The four LANDSAT 5 TM images of the study area

The Normalized Difference Vegetation Index (NDVI, Tucker 1979), is a good indicator of the density of the vegetation. It is a quasicontinuous field that is calculated as a normalized diffrence between the reflectance of two biologically meaningful bands of the electromagnetic spectrum. Actively, as a source of energy for photosyhthesis, photosynthesizing leaves absorb the red wavelenghts (LANDSAT TM band 3) and reflect the short-wave infrared (LANDSAT TM band 4). The diffrence between the two is proportional to the amount of photosysthesis (Parodi, 2002; Schreiber, 2006; Gazioğlu, et al., 2014; İslam, et al., 2016; Gazioğlu, et al. 2016; Avşar, et al., 2016; Osgouei and Kaya, 2017; Kaya et al., 2017). NDVI is unaffected by band sharpening since the relative contributions of the near-infrared and red bands remain unchanged by the fusion method (Wiemker, 1998). The reason NDVI is related to derive oasis positions from images vegetation is that healthy vegetation reflects very well in the near infrared part of the spectrum.
In arid zones, the oasis vegetation have a highest chrolophylly activity in quantity (phytomass) and more perennial in time, that the natural vegetation such us steppes. The raw NDVI values are fractional real numbers that range between -1.0 to +1.0 . An NDVI of zero means no green vegetation and close to $+1(0.8$ $0.9)$ indicates the highest possible density of green leaves (Sermin, 2007, Kavacık et al., 2014, and Schreiber, 2006).

Following NDVI index was used :

$$
\begin{aligned}
& N D V I=B 4-B 3 / B 4+B 3 \\
& N D V I=P I R-R / P I R+R \\
& \text { With : } \\
& P I R: \text { reflectance in the Near Infa Red } \\
& R: \text { reflectance in the Red }
\end{aligned}
$$

After that a combining color with TM2, TM3 and TM4 bands was used. The blue coloris affected to the TM2 band; the green color to the TM3 band and the red color to the TM4 band. With this combination of bands and 
colors, vegetation appears on red because it is more reflective in the PIR then in the green and red bands. In that, the vegetation appears in red it helps in visual identification of oasis but it was insufficient to extract automatically oasis positions.

\section{Interpretation of NDVI pixels values}

Ten oases are detected (Gabès, Ghannouch, Kébili, Douz, Gafsa, Mareth, Midès, El Guettar, Nefta, Tozeur-nouveau, Tozeur-ancien). Table 1 explain value intervals of NDVI ([-1;0]; $[0 ; 0,01] ;[0,01 ; 0,02] ; \ldots ;[0,9 ; 1])$ and cells contains conmments on terrain objects. For each oasis and with a path of 0,1 the object composition is discribed. From exemple; in the interval of $[-1 ; 0]$, value of pixel in Gabes presents the sea but in the $[0,2 ; 0,5]$ pixels are positionned in the palm grove.

The oases extracted interval retenu finalement is $[0,2 ; 0,7]$ : au-dessous less this 0,2 NDVI value and more then 0,7 NDVI value, no pixel was detected. So the hypothesis emise is that oases have radiometric value of NDVI index between 0,2 et and 0,7 (figure3).

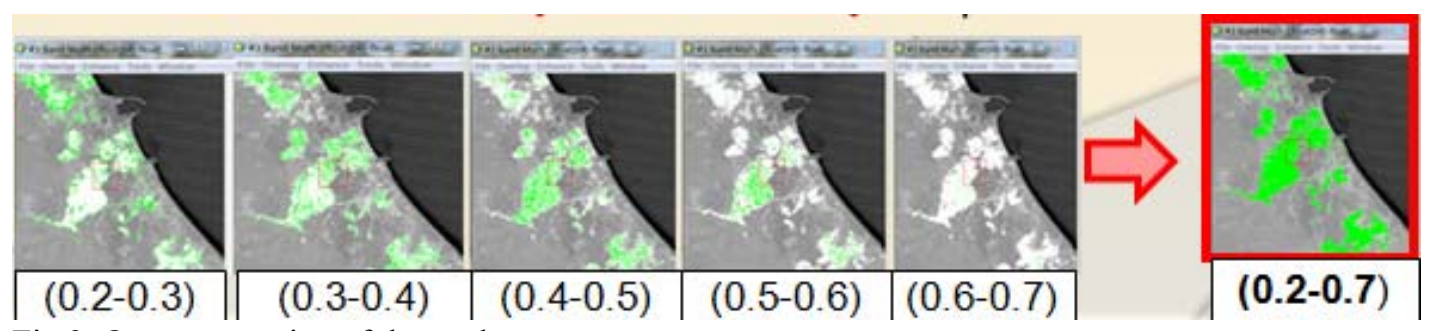

Fig 3. Oases extraction of the study areas

\section{Fields validation by a visual interpretation}

We have used the image processing tool of ENVI Band Math to vectorize a binary image and convert values pixels of oasis from the $[0,2 ; 0,7]$ interval to have a binary image. 1 means an oasis and 0 means other component. A new vector in size (.evf) is obtained. Then, $\mathrm{i}$ twas exported to ArcGIS and a new shapefile is created (.shp). This one is saved in the size (.kmz) and imported to Google Earth Pro view to be validated. The error rate was less $2 \%$ $(n=50)$, then the validation of oasis zones.

Therefore, the number of pixels increases and the interval desciption vary about a gradient oriented north west-south est. From example, the interval descriping urbain zones vary from $[0.04,0.05]$ in Gabes and Gafsa to [0.05, 0.06] in Tozeur. The interval descriping palm grove zones vary from $[0.4,0.5]$ in Gabes and Gafsa to $[0.2,0.25]$ in Tozeur.

\section{Processing Thematic maps}

The thematic maps of vegetation, sols and relief of tunisia according to the National Center of Cartography and remote sensing at a scale were obtained with a scale of 1/1 000000 after digitizing the map vegetation. The vegetation map is presented with a classification of vegetal units with climatic etage characterization (Gammar, 2001): submediterranean, mediterranean, mediterranean-steppic, steppic desertic), each etage was classed in vegetation series. The main type vegetation of a study region belongs three domaines such us steppic mediterranean, steppics predesertic and desertic saharien. And xerosols and regosols mark soil types, however class altitude of relief map despite mountains in the north and coastal in the east.

Thematic maps are digitized using GIS technologies, so for each thematic map a new vector shapefile is created and the attribute table contient description about vegetation dataset, sol dataset or altitude dataset. Then the three new layers containing polygones are superposed, georeferenced and after combined. After intersection of thematic layers, great number of area was obtained, so gathered map was totally unreadable and it was still too much to create sufficient for practical use typological classification landscape. 
For decreasing count of areas, cleaning of some area was applied. In this step polygones without information about sol or vegetation or relief, therefore problem of readability of map comes into question. Partially, this problem was solved by elimination of irrational areas: edges of maps are cleaned then the smaller. So after the new attribute table contains 573 polygones ranged in 296 different classes and her the utility of statistic traitments. However, it was necessary to determine smallest area for visualisation. It was decided that only biggest topological areas are sufficient at this map scale (1:000 000).

\section{Implementation of the Spatial Classification Technique}

To implement the polygones-based classification of the input grids belong to the study area, the elements of the multivariate tool available in the Spatial Analyst tools located in the Toolbox of the ARCGIS 9.3 were utilized. Therefore, the multivariate analysis statistical treatment is used to reduce the number of clusters and to put in evidence enrinoment types of study area. Sofar two kinds of multivariate treatment are used.

The Multiple Correspendance Analysis (MCA) is used to transform all qualitative variables to quantitative one La première étape consiste à réaliser une Analyse des Correspondances
Multiples (ACM). Whith this treatment we have to analyse the data table with new coordinate in factorial axis for eath polygone.

The Decision Tree Analyses was used to classify landscapes and to determine the landscape character mapping by using the Iso Cluster tool. The Iso prefix of the ISODATA clustering algorithm is an abbreviation for the Iterative Self Organizing Data clustering technique. It is an iterative process for computing the minimum Euclidean distance when assigning each candidate cell to a cluster. The process starts with arbitrary means being assigned by the software, one for each cluster as predefined at the beginning. Every cell is assigned to the closest of these means (all in the multidimensional attribute space). New means are recalculated for each cluster based on the attribute distances of the cells that belong to the cluster after the first iteration. Based on userdefined parameters, the process is repeated and the unknown grid polygon data is iteratively grouped together in clusters until either some proportion of pixels' class values remains unchanged or a maximum number of iterations have been reached (Rahman, 2016). This algorithm determines the characteristics of the natural groupings of cells in multidimensional attribute space and store the result in an output ASCII signature file.

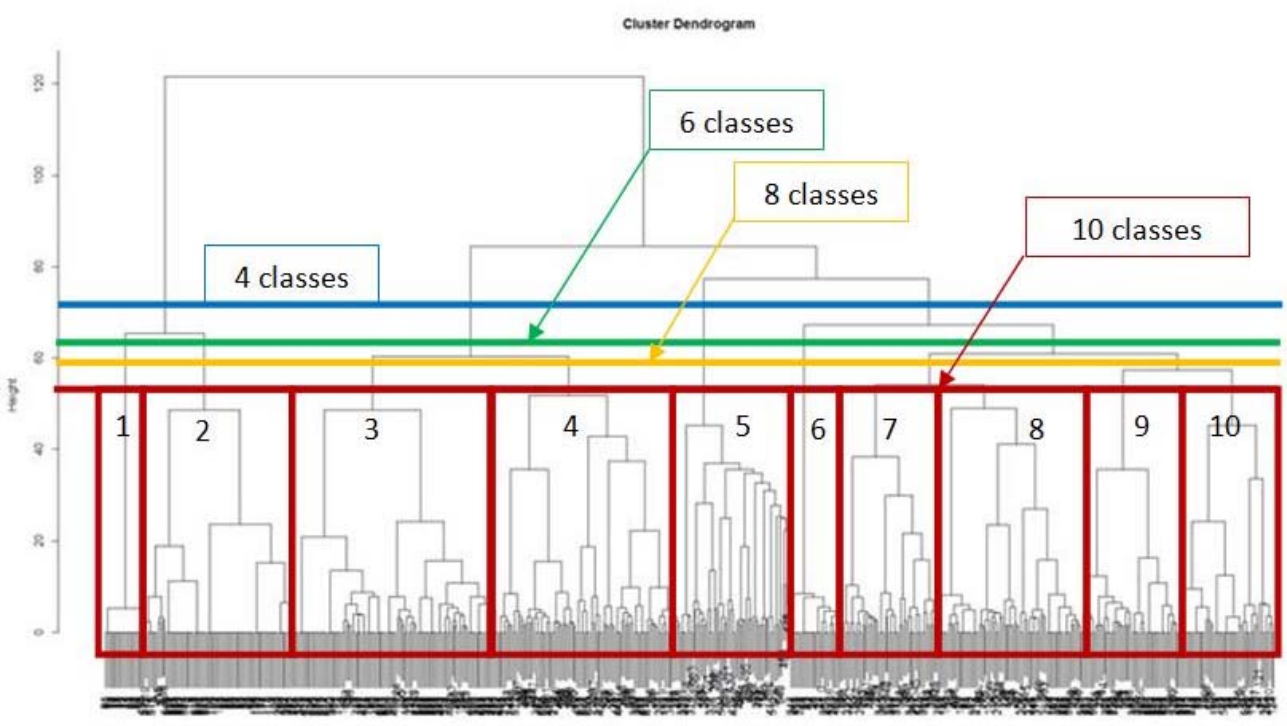

Fig 4. The Dendrogram of the landscape classification 


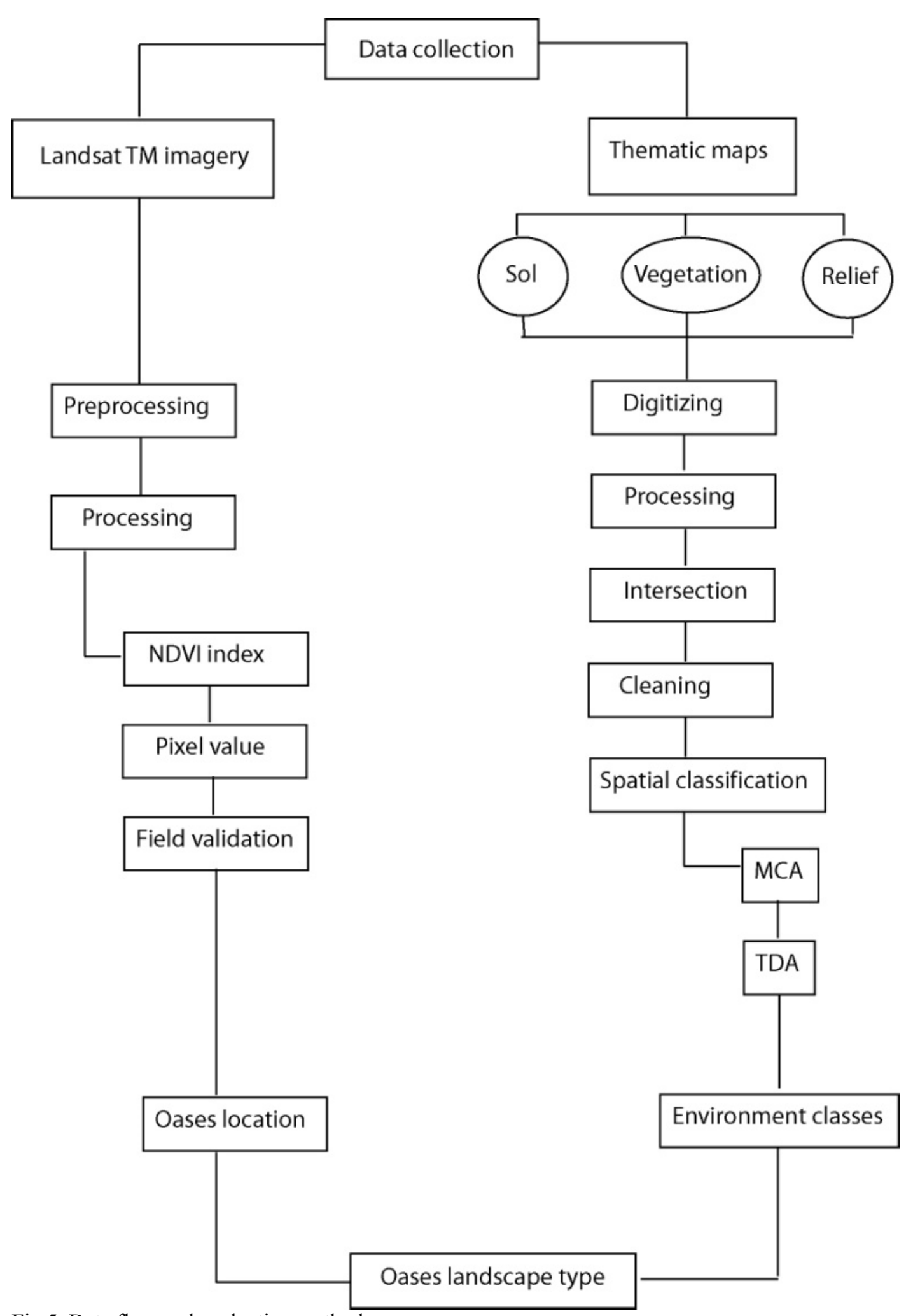

Fig 5. Data flow and evaluation methods 
Hierarchical methods usually produce a graphical output known as a dendrogram or tree that shows this hierarchical clustering structure. These methods are particularly useful in that they are not limited to pre-determined number of clusters and can display similarity of samples across a wide range of scales. Agglomerative hierarchical methods are particularly common in the natural sciences

The results of the classification cluster analysis are shown in figure 4 by a dendrogram, which lists all of the clusters and indicates at what level of similarity any two clusters were joined. The $\mathrm{x}$-axis is some measure of the similarity or distance at which clusters join.

Figure. 5 presents an overview of the data flow and evaluation methods. For each study area, LANDSAT imagery, thematic maps and training data were acquired. Landscapes product were generated using Decision Tree Classification. The landscapes typology were then evaluated using the extract oases.

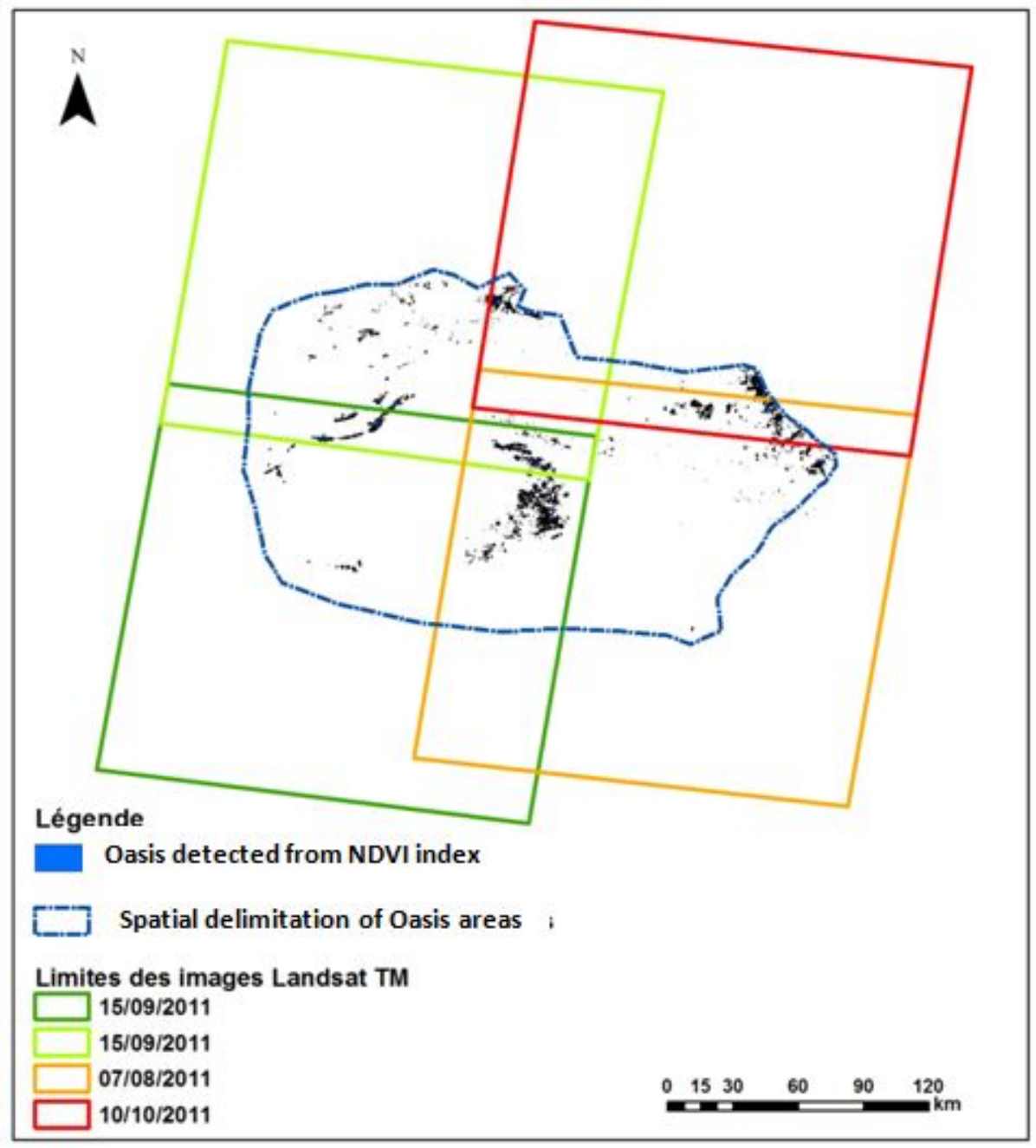

Fig 6. « Oases zones » map extrated from LANDSAT TM images 


\section{Results}

\section{Oasis locations of southern Tunisia}

Figures 6 and 7 watch the spatial localisation of " oases regions » of the study area. There is a significant concentration of oases in the center of the map, spatially in Nefzaoua. In the east there are the coastal oases of Gabes and in the north we find the continental oases of Gafsa. However, a diffuse distribution is noted between Gafsa and Tozeur.

\section{Mapping oasian landscapes typology}

Mapping oasian landscapes typology was constructed from the five maps produced successively via two statistical analyzes. In order to understand what are the main landscapes types and how they become more complexed or refined, five maps were produced by gradually increasing classes number for the major media types obtained. Figure 8 show how the spatial organization of the major types progress as the number of classes increases. Then, the Figure 8 indicates the six landscapes types obtained:

1. Chott El Jerid landscape

2. Chott El Fjej landscape

3. Coastal landscape

4. Northern Dahar landscape

5. Occidental Atlas landscape

6. Oriental Atlas landscape

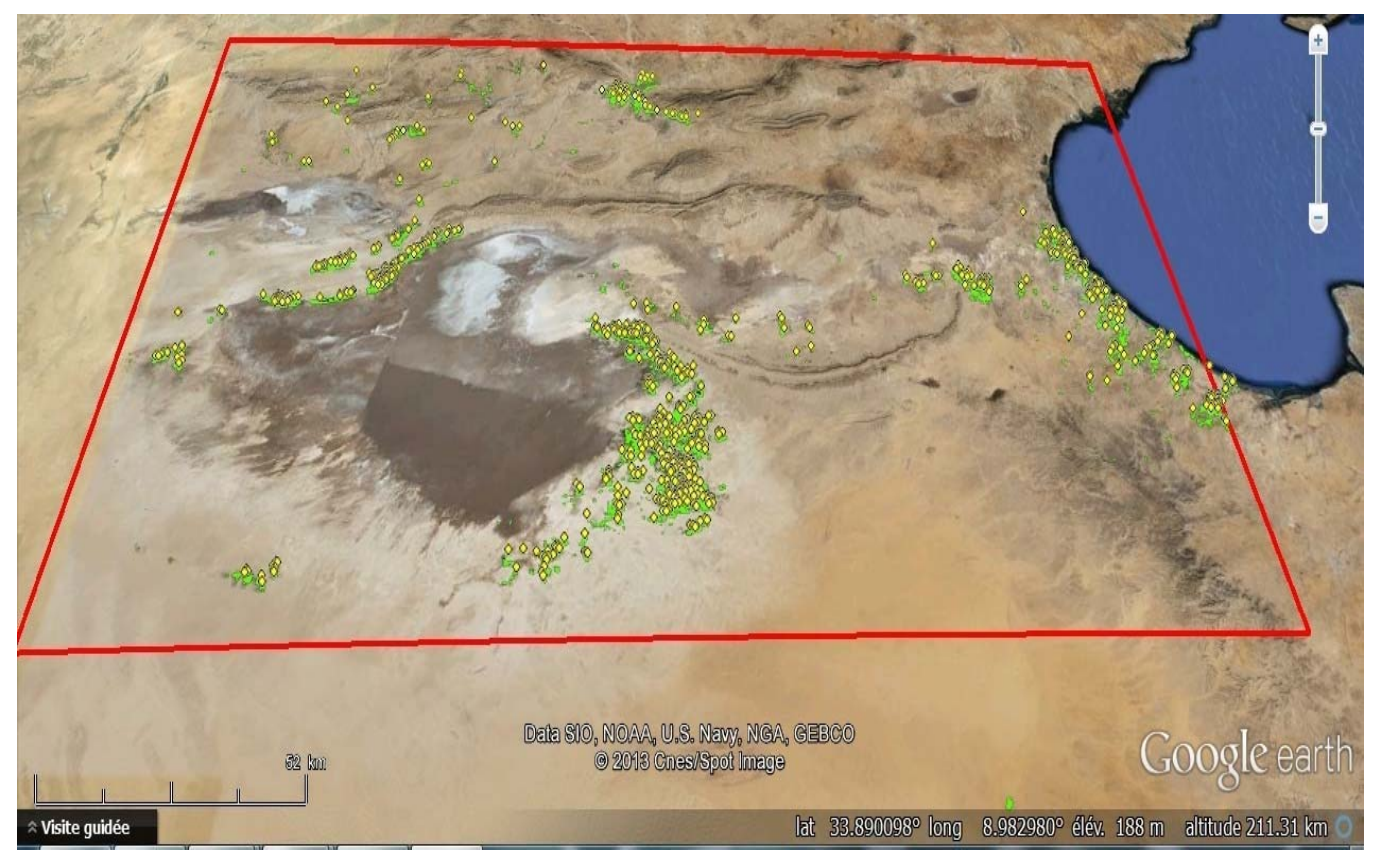

Fig 7. Validation of extrated « oases zones » 


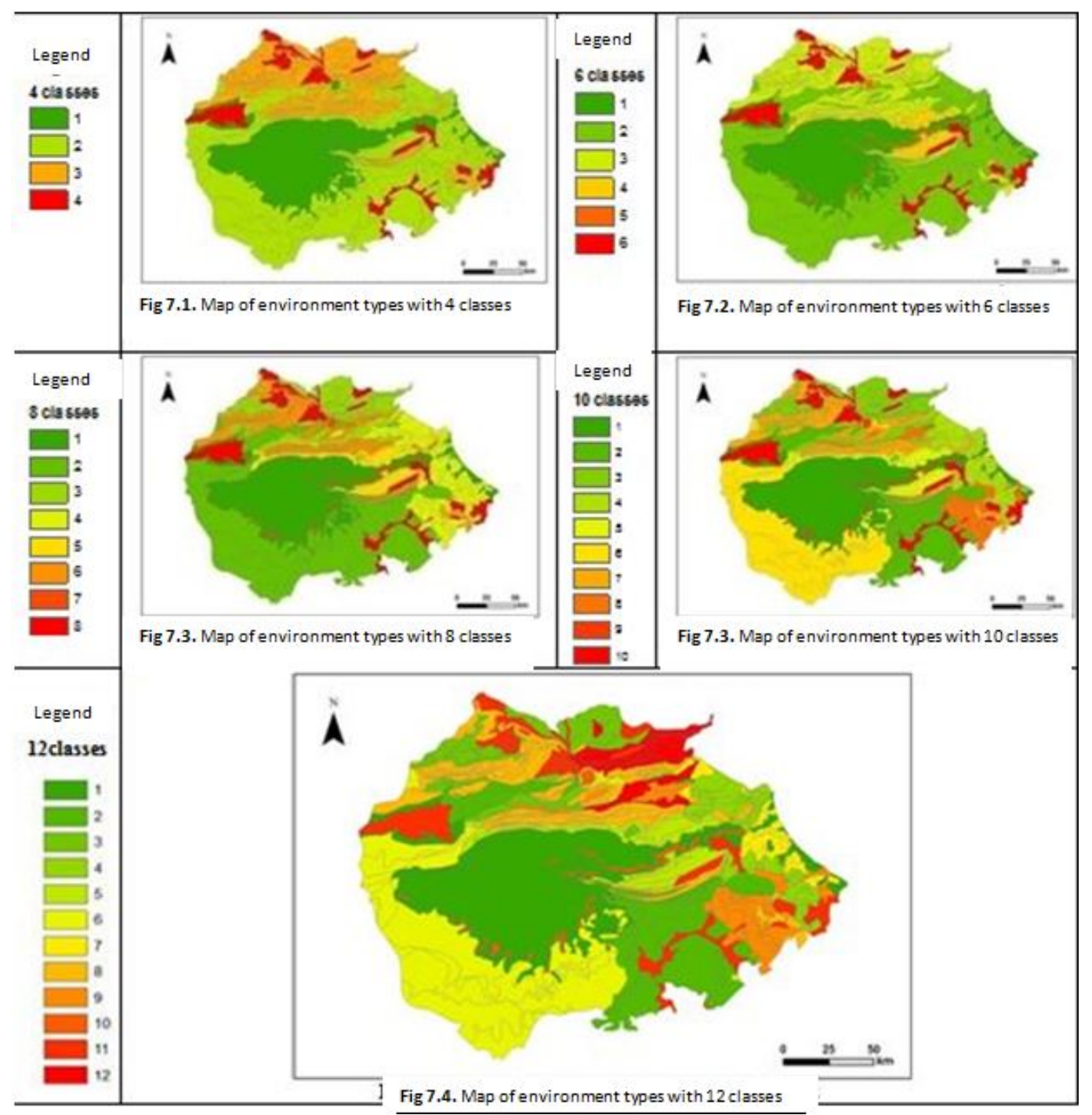

Fig 8. Maps of environment types with differents classes

Chott El Jerid and Chott El Fjej are the most remarkable element of this region because of their extension and their stability when the number of classes of middle families increases. They therefore constitute a relatively homogeneous whole. It is necessary to distinguish these two sectors because they correspond to different landscapes, in the sense that they do not have in the immediate vicinity the same environmental types:

- Chott El Jerid, formed by Class 1, is almost exclusively surrounded by the western 6 family, which grows largely to the northeast and southeast. It is the most spatially extended landscape.
- Chott El Fjej, also formed by class 1 in its center, is rather surrounded by the family 5 sides north and south.

The coastline is less spatially spread and is distinguished from the chotts by the dominance of the family 7 , shared on several polygons. The Northern Dahar consists mainly of the family 9, which forms a relatively compact zone on a relatively large area. The Western Atlas is characterized by a diversity of families with fairly close areas. These are families 2, 3, 8 and 11. The Eastern Atlas is different because it consists mainly of family 12 , with a greater diversity of families. 


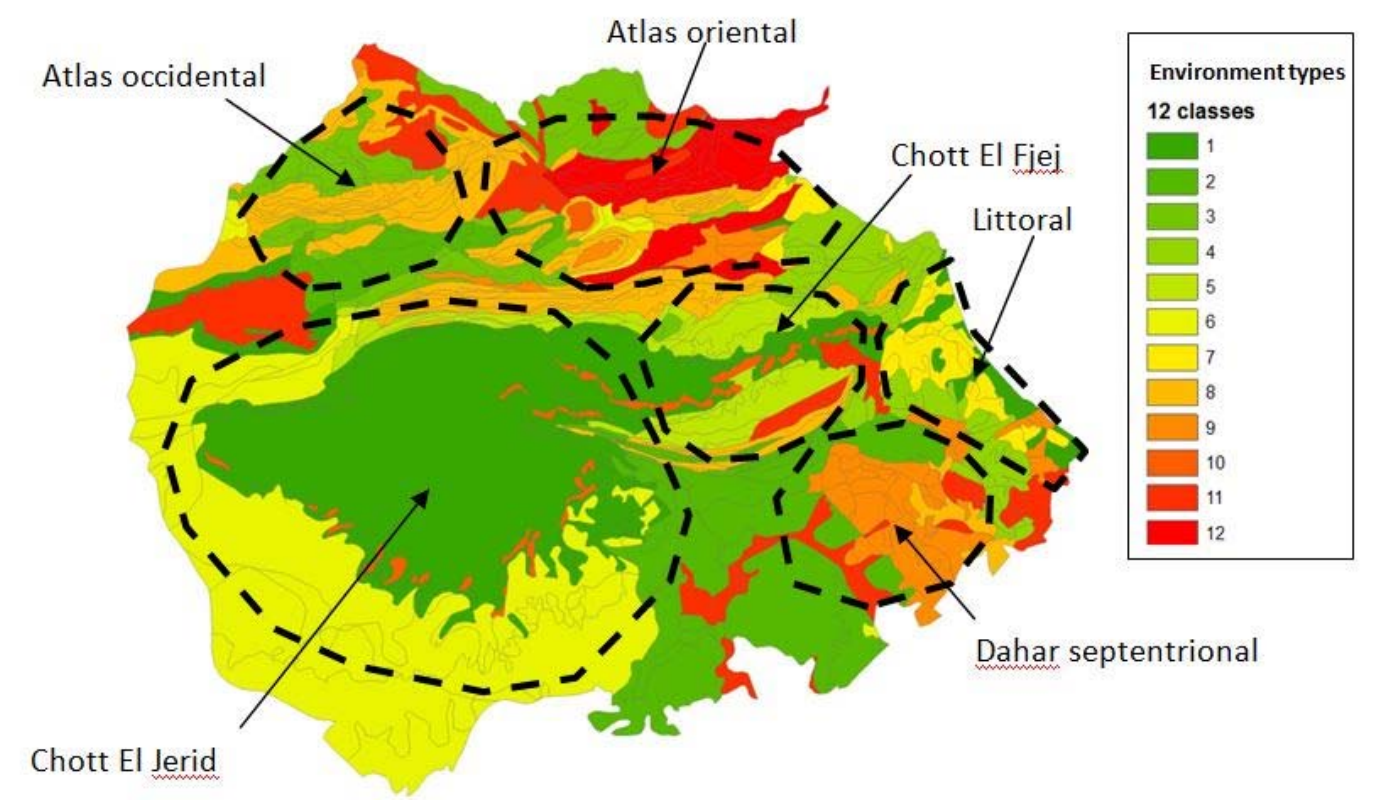

Fig 9. Map of environment types of six landscapes in southern Tunisia

\section{Mapping landscapes types of southern Tunisia}

The superposition of oasis map obtained from the LANDSAT TM images, oasis-NDVI map and landscapes types map, makes it possible to situate the oases in the great landscapes of southern Tunisia (figure 10). The characteristics of the environment classes vary greatly in different areas of South Tunisia; therefore, the whole of the study area was devided into six oases landscapes based on the location of the oases map and the type of environment class.

The rule of delineating landscapes boundaries is accorded to the natural differenciation of the altitude, vegetation and sol zooning. This oasis are: Gafsa-ElGuettar, El Hamma de Gabès, Douz-Kébili, Rjim Maatoug, Tozeur-Nafta and Tamerza Chebika oases.

This study presents the main results arising from the various stages of the methodology implemented as well as the limits and the avenues of improvement to be envisaged. On the methodological protocol: in general, the methodological protocol allowed us to define the oases resulting from the NDVI calculation and to carry out a mapping of oasis landscapes on the study site. Our approach offers the advantage of demonstrating that it is then sufficient to continue the work on a larger scale to map the units of landscapes to better enrich the characterization of these landscapes. But it is necessary to have the necessary data at this scale to do so. However, this method could be tested in other territories. On characterization of landscapes: The combination of the maps obtained after LANDSAT TM image processing, NDVI calculation and digitalization of thematic maps, gave convincing results by referring to the academic knowledge already existing in this territory. The combined use of two statistical analysis methods, ACM and $\mathrm{HAC}$, allowed us to identify classes to produce satisfactory maps in a quasi-automatic manner 


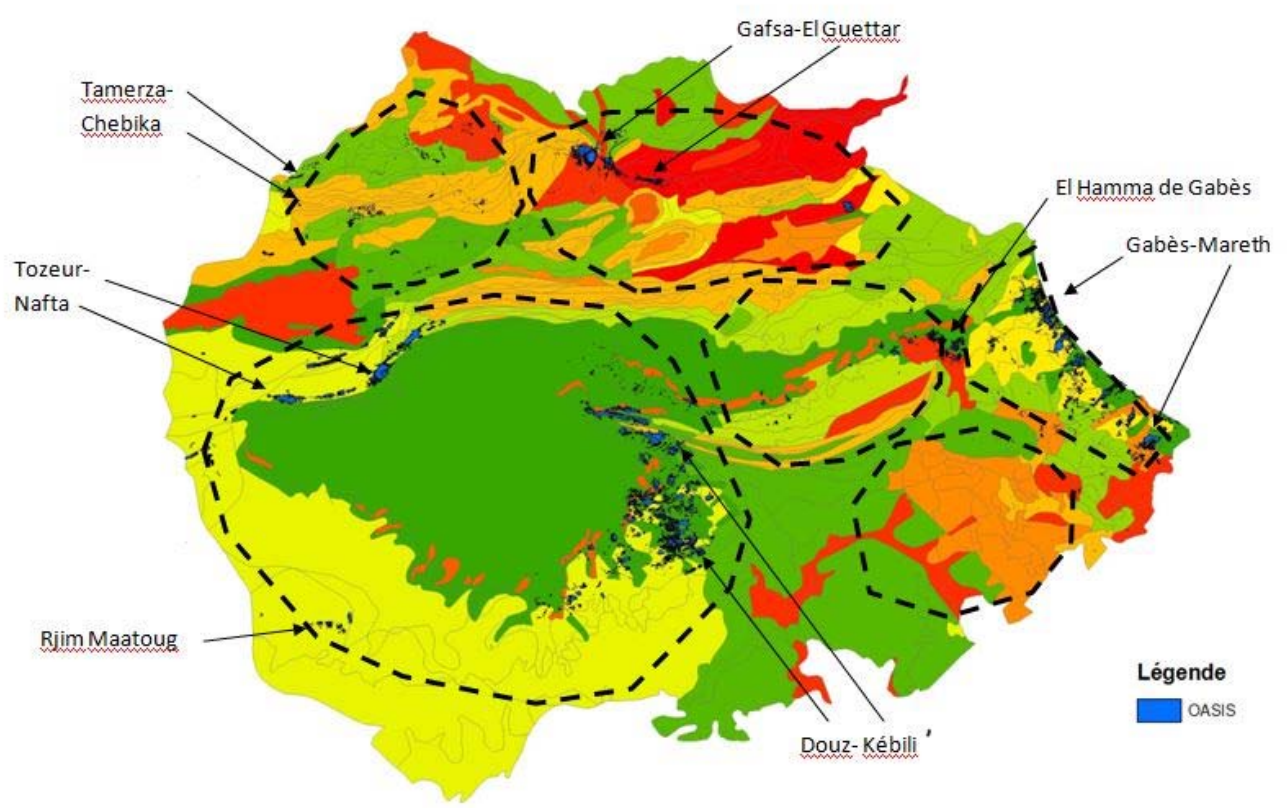

Fig 10. Map of Oases landscapes of the study area

\section{Discussion and Conclusion}

The objective of this study was to evaluate the contribution of geomatics tools, such as remote sensing and GIS for the characterization of landscapes in oasian regions such southern Tunisia. A two-stage methodology was developed: The first one aims at locating oases resulting from remote sensing, using only the NDVI at a given date. The second uses the GIS tool and statistical analyzes to map landscape types of the study site, using three thematic maps (relief, soil and vegetation). We have shown that the classes resulting from the statistical treatments of this variables, are those which have helped us to delimit the main types of landscapes by hand. This study has proved once again the effectiveness of such methods and tools and this on a regional scale which covers an important part of the entire South Tunisia. The NDVI calculation from the LANDSAT TM images allowed a fine extraction of oases which requires no fieldwork thanks to the very high spatial resolution images provided by Google Earth@. This method could easily be applied to other territories. We were able to show that treatments of three thematic maps by GIS and statistical analyzes were sufficient to arrive at six main types of landscapes of Tunisian oasis regions. This work allowed to define a methodology for the construction of landscape types, in a computerized way, based on remote sensing and GIS. This result can be a draft work to make an Atlas of the landscapes of our site of study. By zooming in on each type of landscape, each landscape unit can be characterized. In addition, this final map could be used to organize tourist circus that would enhance the oases of southern Tunisia. It can also be used as a basic document to monitor the spatial extension of agricultural perimeters in order to ensure the sustainable development of these particular agro-systems.

\section{References}

Avşar, E.O., Bozkurtoğlu, E., Aydar, U., Şeker, D.Z., Kaya, Ş. and Gazioğlu, C. (2016). Determining roughness angle of limestone using optical laser scanner. IJEGEO, 3(3), 57-75.

Gammar A. (2001). Carte de végétation de la Tunisie. Office de la topographie et la cartographie Ministre de l'équipement et de l'habitat Nat.3.4. 1/1.000.000. Atlas national. Centre d'étude et de recherches Economique et social secrétariat d'état a la recherche scientifique et a la technologie. 
Gazioğlu, C., Akkaya, M.A., Baltaoğlu, S. and Burrak, S.Z. (2016). ICZM and the Sea of Marmara: The İstanbul Case. The Sea of Marmara: Marine Biodivesity, Fisheries, Conservations and Governanace (Editors: Özsoy, E., Çağatay, M.N., Balkıs, N., Balkıs Çağlar, N., Öztürk, B.): 935-957. Kavacık. 2014. Ilicak, Kumçay and Marmara lake bassins, Turkey. Turkish Journal of Applied Sciences 7 (14): 1827-1842.

Gazioğlu, C., Alpar, B., Yücel, ZY., Müftüoğlu, AE., Güneysu, C., Ertek, TA, Demir, V. and Kaya, H. (2014). Morphologic Features of Kapıdağ Peninsula and its Coasts (NWTurkey) using by Remote Sensing and DTM. IJEGEO, Vol. 1(1): 48-63.

Islam, K., Jashimuddin, M., Nath, B., Nath, T.K. (2016). Quantitative assessment of land cover change using landsat time series data: case of Chunati Wildlife Sanctuary (CWS), Bangladesh, IJEGEO 3(2): 45-55

Kaya, Ş., Çelik, B., Gazioğlu, C., Algancı, U. and Şeker, DZ. (2017). Assessment of the Relationship between Land Cover and Land Surface Temperatures Utilizing Remotely Sensed Data: A Case Study of Silivri, 19th MESAEP Symposium on Environmental and Health Inequity., Roma, ITALYA, 3-6 Dec 2017

Lasram. M. (1990). Les systèmes agricoles oasiens dans le Sud de la Tunisie. Options méditerrannées. Série A. Séminaires Méditerranéens. 11: 21-27.

Le Houérou. H. (1959). Ecological and Floristic Researches on the Vegetation of the Southern Tunisia. Institute of Research on the Sahara, Algeria (Book)

Lillesand. T. M and Kiefer. R. W. (1994). Remote sensing and image interpretation. New York, John Wiley and Sons. 750p.

Luedeling. E. and Buerkert. A. (2008). Typology of oases in northern Oman based on LANDSAT and SRTM imagery and geological survey data. Remote Sensing of Environment 112: 1181-1195

Osgouei, P.E. and Kaya, Ş. (2017). Analysis of land cover/use changes using Landsat 5 TM data and indices, Environmental monitoring and assessment, Vol. 189(4): 136.
Parodi. G. N. (2002), AHVRR hydrological analysis system: User manual version 1.3. AHAS User Guide. Enschede, ITC.

Sahar A. El_Rahman. (2016). Hyperspectral Image Classification Using Unsupervised Algorithms.(IJACSA) International Journal of Advanced Computer Science and Applications, Vol. 7(4). doi.org/10.14569/IJACSA.2016.070425

Santodirocco. F. (1986). Le oasi continentale dei sud tunisino : problematicche e avvenire. Rivesta di Agricoltora Subtropicale e Tropicale; 80 (2): 143-164.

Schreiber. K. V. (2006). An approach to monitoring and assessment of desertification using integreted geospatial technologies. In : Proceedings of the 17 th Conference on Biometeorology and Aerobiology, 24 May 2006. San Diego, CA.

Sermin. T. (2007). Monitor land degradation phenomena through landscape metrics and NDVI: Gödes.

Wiemker. R., Prinz B., Meister. G., Franck., and Spitzer. H.(1998). Accuracy assessment of vegetation monitoring with high spatial resolution satellite imagery. In Proceedings of the ISPRS Commission VII Symposium, ECOBP'98 WG3, 1-4 September 1998, Budapest: 285-295. 